\title{
Methodology for the determination of gaseous hydrogen peroxide in ambient air*
}

\author{
P. Jacob ${ }^{1}$, T. M. Tavares ${ }^{2}$, and D. Klockow ${ }^{1}$ \\ 1 Fachbereich Chemie, Universität Dortmund, D-4600 Dortmund 50, Federal Republic of Germany \\ 2 Instituto de Quimica, Universidade Federal da Bahia, RB-40000 Salvador, BA, Brazil
}

\section{Methodik zur Bestimmung von gasförmigem Wasserstoffperoxid in Umgebungsluft}

Zusammenfassung. Ein Verfahren zur Bestimmung von gasförmigem Wasserstoffperoxid in Umgebungsluft wird beschrieben. Die vorgeschlagene Verwendung eines KryoSammlers $\left(-45^{\circ} \mathrm{C}\right)$ stellt insofern eine Verbesserung gegenüber der bisher üblichen Waschflaschen-Probenahme dar, als damit die bei Absorption in flüssiger Phase beobachteten Artefakte - Bildung und auch Zersetzung von Wasserstoffperoxid - deutlich vermindert werden. Feldmessungen, die zwischen Oktober 1984 und Juli 1985 auf dem Gelände der Universität Dortmund durchgeführt wurden, ergaben mittlere $\mathrm{H}_{2} \mathrm{O}_{2}$-Gasphasenkonzentrationen um 30 pptv. Darüber hinaus werden die Ergebnisse erster Versuche mit beschichteten Diffusionsabscheidern als Sammler für gasförmiges Wasserstoffperoxid vorgestellt.

Summary. A method for the determination of gaseous hydrogen peroxide in ambient air is described. The cryogenic sampling technique $\left(-45^{\circ} \mathrm{C}\right)$ employed represents an improvement compared with the impinger technique by diminishing artifacts which are bound to liquid phase production and decomposition, respectively. Results are given of $\mathrm{H}_{2} \mathrm{O}_{2}$ measurements from October 1984 to July 1985 in Dortmund (FRG), with mean concentrations of about $30 \mathrm{ppt}(\mathrm{v} / \mathrm{v})$. Preliminary results obtained with a coated denuder as a sampling device are also presented.

For several years increasing interest is focussed on atmospheric hydrogen peroxide, not only because of its oxidizing potential in the liquid phase [1-4], but also because of its impact on atmospheric radical chemistry. Here it may act as a sink for $\mathrm{HO}_{2}$ [5]

$2 \mathrm{HO}_{2} \rightarrow \mathrm{H}_{2} \mathrm{O}_{2}+\mathrm{O}_{2}$

and as a source of $\mathrm{OH}$ radicals [6]

$\mathrm{H}_{2} \mathrm{O}_{2} \stackrel{h v}{\longrightarrow} 2 \mathrm{OH}$.

These radicals on their part are the most important oxidizing species for the transformation of atmospheric pollutants [7].

* Dedicated to Prof. Dr. H. Monien on the occasion of his 60 th birthday

Offprint requests to: D. Klockow
There is an urgent need to have a reliable method for $\mathrm{H}_{2} \mathrm{O}_{2}$ measurements in ambient air, not only to verify model calculations [8-11], but also to investigate the distribution of $\mathrm{H}_{2} \mathrm{O}_{2}$ between gas and liquid phase [9] under real atmospheric conditions.

The most widely employed collection method for gaseous $\mathrm{H}_{2} \mathrm{O}_{2}$ was the trapping in impingers [12-21] until Zika and Saltzman [22] and Heikes et al. [23, 24] showed the problems inherent in such a sampling approach. On the one hand, artificial $\mathrm{H}_{2} \mathrm{O}_{2}$ is produced by $\mathrm{O}_{3}$ and other non-identified precursors at the glass surface during the sampling process, and on the other hand losses can be observed caused by the reaction of hydrogen peroxide with reducing air components, particularly $\mathrm{SO}_{2}$. Another sampling method is based on the condensation of water vapor onto a cooled surface [25-27], but with the same disadvantage of having a liquid medium and therefore favorable conditions for dissolution of other possibly interfering and reacting gases, such as $\mathrm{SO}_{2}$ [23]. In the present study we chose the collection by water vapor condensation at about $-45^{\circ} \mathrm{C}$, thus avoiding a liquid phase being formed during sampling.

Several authors have determined hydrogen peroxide in aqueous solution photometrically $[14,18,19,25]$, by a chemiluminescence procedure using luminol as a reagent $[12,13,15,16,20,21,27,28]$, or by employing a fluorimetric enzyme technique [16, 21, 29, 32]. In this work we have made use of the chemiluminescent reaction between hydrogen peroxide and bis-(2,4,6-trichlorophenyl)oxalate (TCPO) in a borate buffer medium of $\mathrm{pH} 8$. Method and instruments are described elsewhere [30].

\section{Experimental}

In the water vapor condensation approach for collection of gaseous substances, sampling device and experimental conditions are the result of a compromise between freezing temperature of gases to be sampled, volume of sample required, time resolution necessary, and load capacity of the cooling surface. (Too thick frozen layers lead to liquid film formation at the ice/air boundary layer.) The volume sampled depends on the sampling efficiency given by that fraction of airborne water vapor which is condensed to ice, assuming equal percentages of the present $\left(\mathrm{H}_{2} \mathrm{O}_{2}\right)_{\mathrm{g}}$ to cocondensate. Cooling area, cooling surface temperature, and air flow rate are influencing efficiency, whereas the absolute water vapor content of ambient air determines the time necessary for sampling an amount of ice sufficient for analysis. 


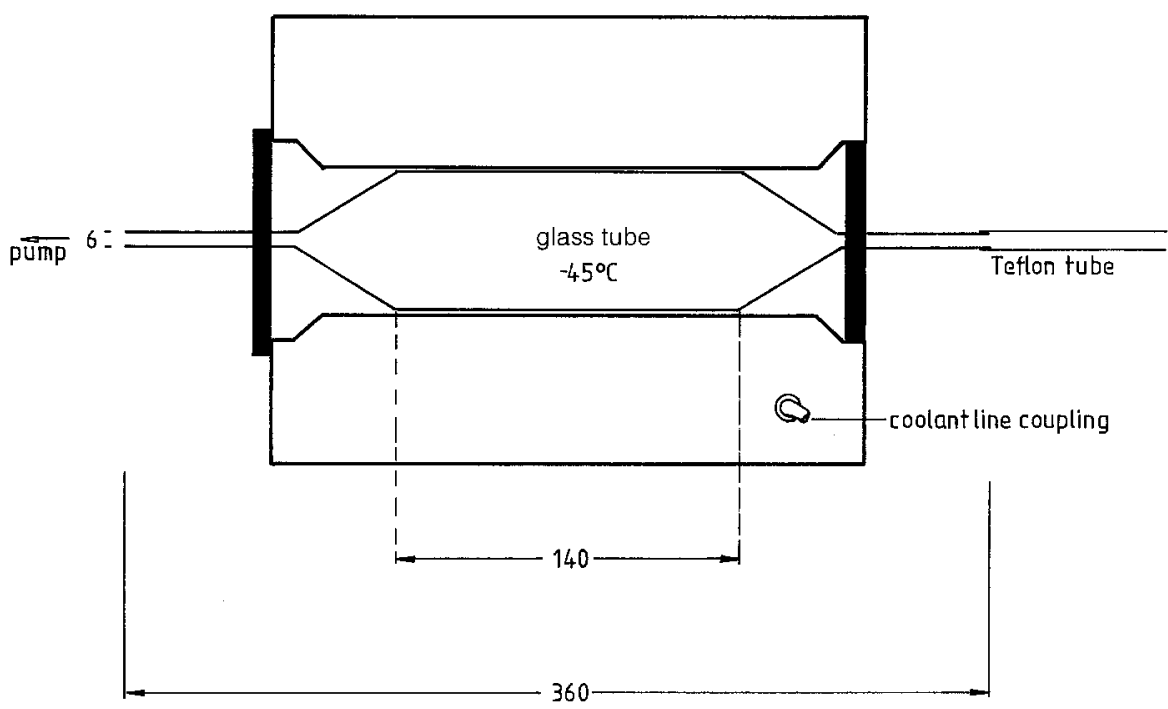

Fig. 1

Cryogenic sampling system, dimensions in $\mathrm{mm}$ (Refrigerator: Products for Research, Inc.; Type: TE-149 TS-RF)
The cooled trap used consists of an electrically operated cooling house normally applied for photomultiplier cooling and a glass tube of compatible dimensions (Fig. 1). The lowest surface temperature possible of the sampling tube, $-45^{\circ} \mathrm{C}$ (reached within $20-30 \mathrm{~min}$ after switching on the cooling aggregate), was used to avoid the formation of liquid droplets or even a liquid film at the cooled surface. The sampling flow rates were between 0.7 and $1.3 \mathrm{~m}^{3} \cdot \mathrm{h}^{-1}$. Too slow fluxes, e.g. $100 \mathrm{l} / \mathrm{h}$, led to clogging of the inlet of the glass tube by frozen water. The smaller the temperature difference is between incoming and outgoing air, the lower is the collection efficiency. In our sampling conditions, temperature differences of about $20^{\circ} \mathrm{C}$ were obtained for air at $0-27^{\circ} \mathrm{C}$ passing through the cooled trap, such yielding sampling efficiencies of $40-30 \%$.

Higher ambient temperatures may lead to a decrease in temperature differences between incoming and outgoing air, with additional danger of liquid film formation at the ice/ air boundary layer. However, this effect can be overcome by employing lower air flow rates. The necessary sampling time depends on the water vapor content of the air under study.

At a relative humidity range of $30-100 \%$, a sample volume sufficient for analysis (ca. $2 \mathrm{ml}$ ) can be obtained within $1 \mathrm{~h}$, which enables a reasonable resolution in time. Maximum sampling time is limited by the load capacity of the cooling surface.

Although a liquid nitrogen trap would work with higher efficiency, its use would be unsuitable in the particular case of $\mathrm{H}_{2} \mathrm{O}_{2}$ sampling. This is because ozone would also be condensed and this represents a potential source of artificial hydrogen peroxide.

Air samples have been taken in $1.5 \mathrm{~m}$ altitude above ground during the period of August 1984 to July 1985 at a site on the campus of the University of Dortmund. After sampling, the glass tubes, internally coated with ice and cocondensed atmospheric trace components, were closed at both ends with little polypropylene tubes (type Eppendorf) and stored in a freezer $\left(-20^{\circ} \mathrm{C}\right)$ until being taken for analysis. Alternatively, the content of a sampling tube was directly melted under warm tap water and transferred to a polypropylene vessel for immediate analysis, thus allowing only little time for decomposition of $\mathrm{H}_{2} \mathrm{O}_{2}$ by possibly present reducing agents. $1 \mathrm{ml}$ of a sample solution was buffered with $200 \mu$ of $0.5 \mathrm{M}$ borate buffer (pH 8) and injected into the flow analyser. Results were obtained by standard addition technique [30].

In order to verify that the $\mathrm{H}_{2} \mathrm{O}_{2}$ concentration found in the condensed water phase can be directly related to the water vapor content of ambient air, a second cooling trap with dry ice/acetone has been used in series with the first one in a number of experiments. The $\mathrm{H}_{2} \mathrm{O}_{2}$ concentrations in the solutions obtained from the two traps differed by less than $10 \%$ most of the time, indicating that no serious fractionation of $\left(\mathrm{H}_{2} \mathrm{O}_{2}\right)_{\mathrm{g}}$ and water vapor takes place during sampling. Therefore, the concentration of gaseous $\mathrm{H}_{2} \mathrm{O}_{2}$ in ambient air, $\left[\mathrm{H}_{2} \mathrm{O}_{2}\right]_{\mathrm{g}}$, expressed in $\mathrm{ng} \cdot \mathrm{m}^{-3}$, can be calculated in the following way:

$\left[\mathrm{H}_{2} \mathrm{O}_{2}\right]_{\mathrm{g}}=\left[\mathrm{H}_{2} \mathrm{O}_{2}\right]_{\mathrm{i}} \times\left[\mathrm{H}_{2} \mathrm{O}\right]_{\mathrm{g}}$.

Here $\left[\mathrm{H}_{2} \mathrm{O}_{2}\right]_{1}$ is the concentration of $\mathrm{H}_{2} \mathrm{O}_{2}$ in the liquid water from the trap in ppbw, and $\left[\mathrm{H}_{2} \mathrm{O}\right]_{\mathrm{g}}$ is the water vapor content in $\mathrm{g} \cdot \mathrm{m}^{-3}$ of the air under investigation at given temperature and relative humidity.

The limit of detection of the chemiluminescence technique is $0.4 \mathrm{ppbw}$ of $\mathrm{H}_{2} \mathrm{O}_{2}$ in aqueous solution. For the determination of $\mathrm{H}_{2} \mathrm{O}_{2}$ in the gas phase, combining cryo sampling with chemiluminescence analysis, meteorological parameters such as temperature and relative humidity have to be taken into account for the estimation of the overall detection limit. This can be taken from the examples in Table 1.

As can be seen, the limits of detection are higher during summer. But generally the $\mathrm{H}_{2} \mathrm{O}_{2}$ concentrations in air are also higher in summer, so that reliable determinations can be carried out during all the year (see Table 2).

For comparison three sampling trains were operated in parallel, one containing the cryogenic collector, and two equipped with an impinger. Both impingers were fitted with a glass frit as air inlet, filled with $10 \mathrm{ml}$ of water, stored in an ice bath at $0^{\circ} \mathrm{C}$ and protected against light. The results obtained are shown in Table 3.

The rather low $\mathrm{pH}$-values and high conductivities of the absorber solutions suggest that the impingers are much more unselective and are collecting a significantly higher mass fraction of airborne matter, gases and particles, than the cryogenic trap. Most probably the higher levels of $\mathrm{H}_{2} \mathrm{O}_{2}$ 
Table 1. Limits of detection, (LD) , for the determination of $\left(\mathrm{H}_{2} \mathrm{O}_{2}\right)_{\mathrm{g}}$ in ambient air employing cryogenic sampling as a function of relative humidity and temperature

\begin{tabular}{|c|c|c|c|}
\hline \multicolumn{2}{|c|}{ Parameter } & \multirow{2}{*}{$\begin{array}{l}\text { Water vapor content } \\
\left(\mathrm{g} / \mathrm{m}^{3}\right)\end{array}$} & \multirow{2}{*}{$\begin{array}{l}(\mathrm{LD})_{\mathrm{g}} \\
(\mathrm{pptv})\end{array}$} \\
\hline r.h.: & $95 \%$ & & \\
\hline$T:$ & $25^{\circ} \mathrm{C}$ & 21.5 & 6 \\
\hline r.h.: & $80 \%$ & & \\
\hline$T:$ & $0^{\circ} \mathrm{C}$ & 3.8 & 1 \\
\hline r.h.: & $50 \%$ & & \\
\hline$T:$ & $-15^{\circ} \mathrm{C}$ & 0.8 & 0.2 \\
\hline
\end{tabular}

Table 2. Mean and maximum $\left(\mathrm{H}_{2} \mathrm{O}_{2}\right)_{\mathrm{g}}$ concentrations in air at Dortmund in different seasons

\begin{tabular}{rcrc}
\hline \multirow{2}{*}{ Month } & \multirow{2}{*}{$\begin{array}{l}\text { Number } n \text { of days } \\
\text { with measurements }\end{array}$} & \multicolumn{2}{c}{ Daily concentrations (pptv) } \\
\cline { 3 - 4 } & & mean & maximum \\
\hline 8.84 & 5 & 39 & 220 \\
10.84 & 7 & 35 & 110 \\
11.84 & 20 & 15 & 55 \\
12.84 & 12 & 5 & 10 \\
6.85 & 7 & 52 & 220 \\
7.85 & 6 & 60 & 215 \\
\hline
\end{tabular}

found with impinger sampling are due to uncontrolled artificial $\mathrm{H}_{2} \mathrm{O}_{2}$ production.

\section{Results of field measurements}

Results of measurements in the period between October 1984 and July 1985 are shown in Figs. 2-5. From these some conclusions can be derived:

- The $\left(\mathrm{H}_{2} \mathrm{O}_{2}\right)_{\mathrm{g}}$ concentrations are very low compared to those found by other authors $[12,15,16,19,27,28]$. Exceptional agreement is achieved with results reported already in 1878 by Schöne $(150-300$ pptv) [25].

- On days with a clear sky the concentrations exhibit a distinct diurnal variation with maxima in the afternoon.
The daytime mean concentration between October and December 1984 is 27 pptv compared with 14 pptv at night. In June and July the relation is 55 pptv to $16 \mathrm{pptv}$. The fast decrease of the $\left(\mathrm{H}_{2} \mathrm{O}_{2}\right)_{\mathrm{g}}$ concentrations during evening and night is not easy to interpret, considering that the estimated lifetime of $\mathrm{H}_{2} \mathrm{O}_{2}$ is about 1 day (Chameides and Davis [33]) and that only photolysis and rain-out or wash-out should be effective sinks. It might be possible that deposition with dew is responsible for the observed phenomenon.

- Rain events lead to wet removal of gas phase $\mathrm{H}_{2} \mathrm{O}_{2}$. Observations have shown, however, that a decrease in concentration starts already with increasing cloudiness. This may be due to advection of humid air masses which have lost a substantial fraction of gaseous $\mathrm{H}_{2} \mathrm{O}_{2}$ by uptake through liquid droplets.

In order to describe the behaviour of $\mathrm{H}_{2} \mathrm{O}_{2}$ in ambient air, its distribution between gas and liquid phase under atmospheric conditions has to be investigated. For this reason $\mathrm{H}_{2} \mathrm{O}_{2}$ concentrations in rain and in the gas phase were measured simultaneously during a complete $52 \mathrm{~min}$ event on September 13, 1985 (Fig. 6). From the concentrations found in rain and with a Henry's law constant for pure water of $1.7 \times 10^{5}$ moles $1^{-1} \mathrm{~atm}^{-1}\left(15^{\circ} \mathrm{C}\right)$ [3] gas phase concentrations of $\mathrm{H}_{2} \mathrm{O}_{2}$ were calculated and then compared with measured ones (Table 4).

From Fig. 6 and Table 4 it can be seen that, in the beginning of the rain event, high concentrations of $\mathrm{H}_{2} \mathrm{O}_{2}$ are present in the liquid phase. Close to the ground, the $\mathrm{H}_{2} \mathrm{O}_{2}$ mixing ratio found in the gas phase is much lower than correspondent to the gas-liquid equilibrium. Therefore no significant change in the $\mathrm{H}_{2} \mathrm{O}_{2}$ gas phase concentration due to wash-out was noticed in the first period of the event. As the event proceeds, the rain becomes poorer in $\mathrm{H}_{2} \mathrm{O}_{2}$, so that slowly a transition state is achieved, where calculated and measured $\left(\mathrm{H}_{2} \mathrm{O}_{2}\right)_{\mathrm{g}}$ concentrations are in agreement. Towards the end of the event, rain becomes subsaturated with respect to $\mathrm{H}_{2} \mathrm{O}_{2}$ and starts to scavenge $\mathrm{H}_{2} \mathrm{O}_{2}$ from the gas phase where measured $\left(\mathrm{H}_{2} \mathrm{O}_{2}\right)_{\mathrm{g}}$ concentrations are higher than the calculated ones.

Different processes can account for the observed changes in $\mathrm{H}_{2} \mathrm{O}_{2}$ concentrations in collected rain water during the event: below-cloud scavenging of gaseous $\mathrm{H}_{2} \mathrm{O}_{2}$ (different in different altitudes), partial evaporation of rain drops in the initial period of the event, production or consumption of $\mathrm{H}_{2} \mathrm{O}_{2}$ [23], and decrease of $\mathrm{H}_{2} \mathrm{O}_{2}$ gas phase concentration in clouds during the event.

Table 3. Results of comparative measurements of $\left(\mathrm{H}_{2} \mathrm{O}_{2}\right)_{\mathrm{g}}$ obtained by employing two different sampling procedures, a cryogenic trap and two impingers in parallel, respectively

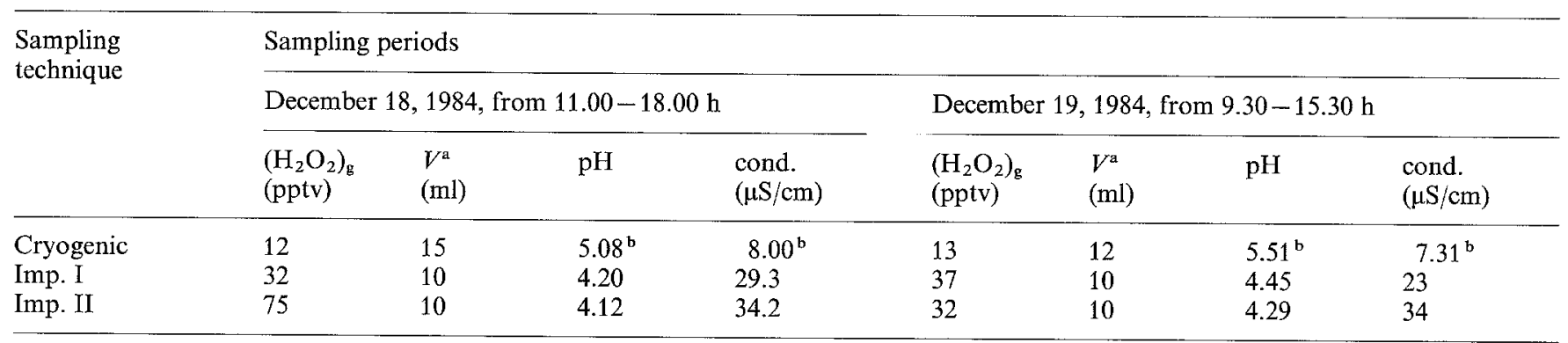

Sampling rate was $700 \mathrm{l} / \mathrm{h}$ for the cryogenic trap and $65 \mathrm{l} / \mathrm{h}$ for Imp. I and $69 \mathrm{l} / \mathrm{h}$ for Imp. II

${ }^{a} V$ Total volume of the aqueous sample solution

${ }^{\mathrm{b}} \mathrm{pH}$-values and conductivities of the melted samples 

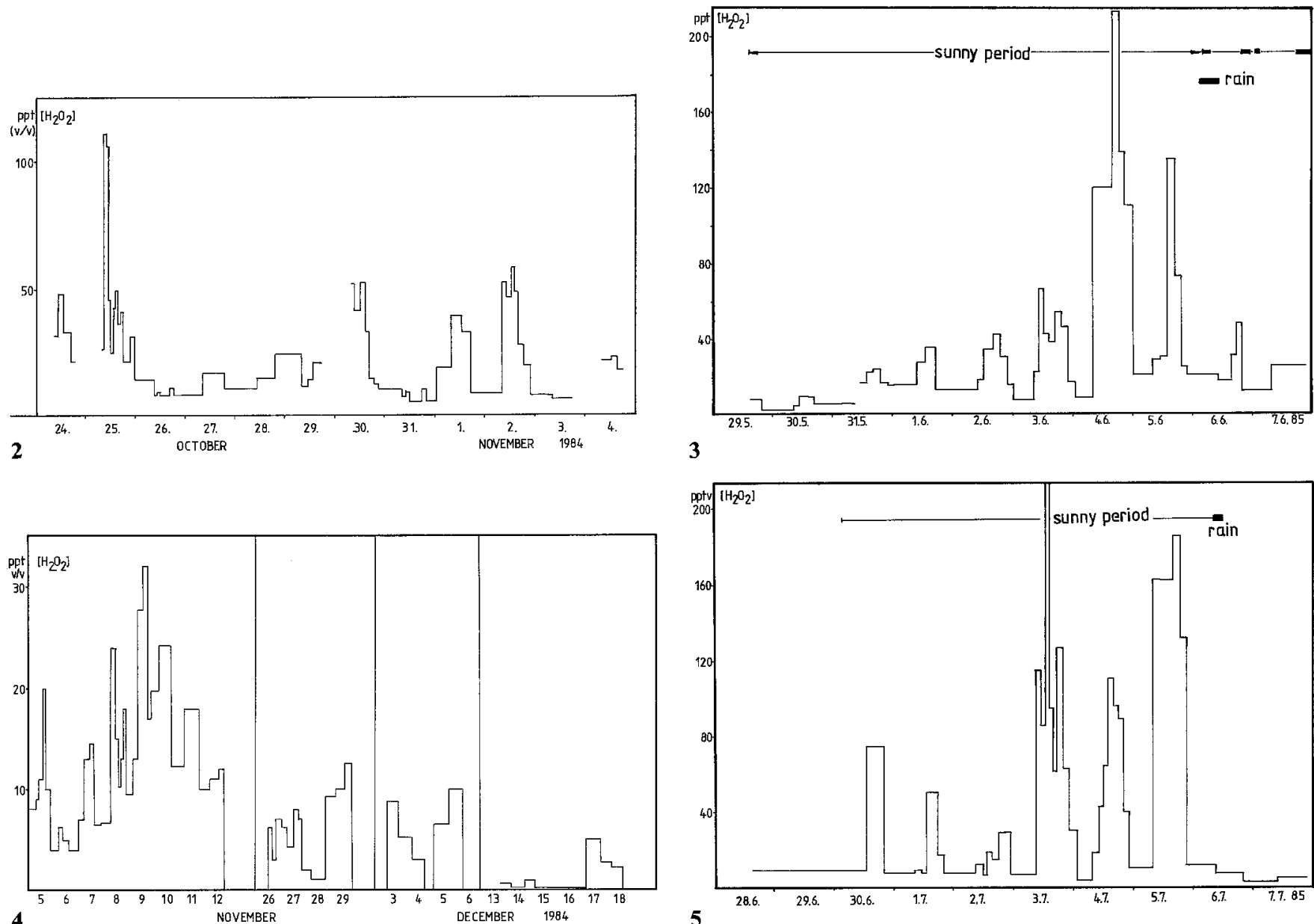

3

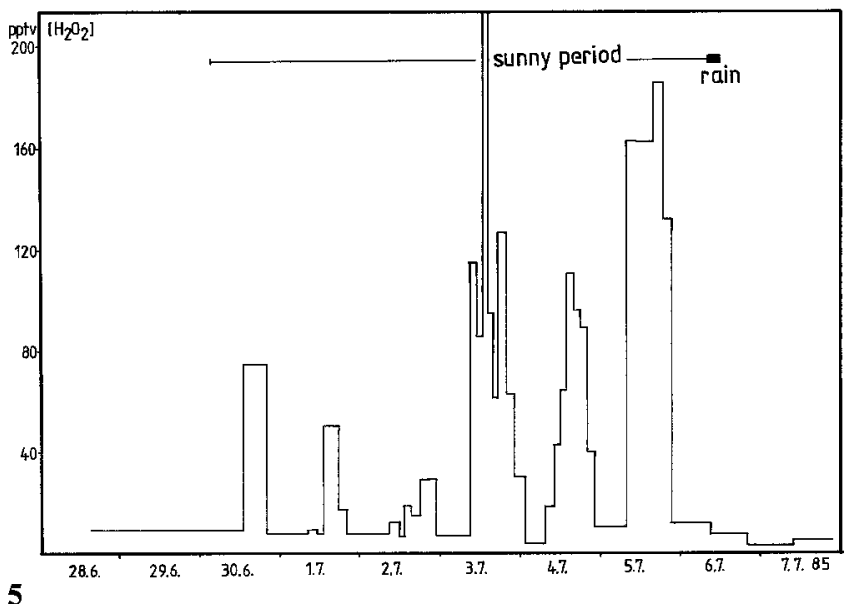

Figs. 2-5. $\mathrm{H}_{2} \mathrm{O}_{2}$ concentration in ambient air; Campus of the University of Dortmund

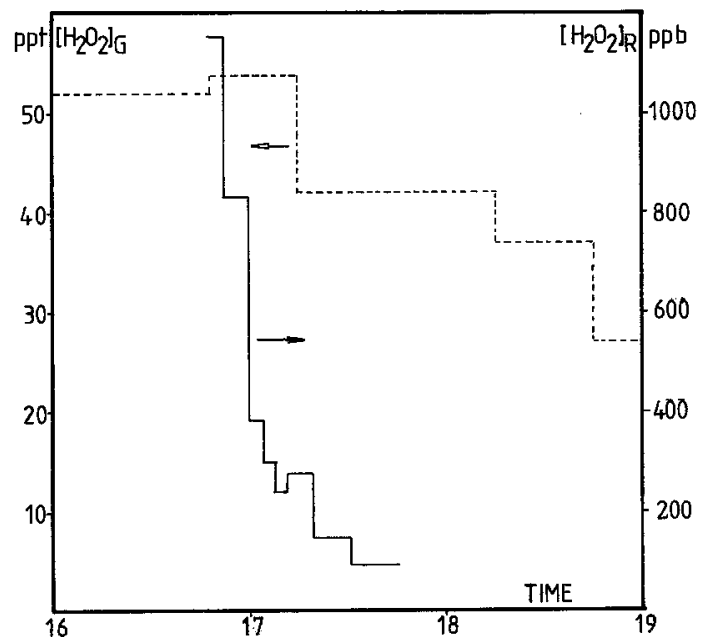

Fig. 6. $\mathrm{H}_{2} \mathrm{O}_{2}$ concentration in rainwater $(-)$ and in ambient air (---) during a precipitation event on September 13, 1985

\section{Further investigations}

In order to make the sampling equipment smaller and more convenient for field use, and also to avoid possible losses of $\mathrm{H}_{2} \mathrm{O}_{2}$ due to scavenging by non-settling ice particles formed in the cryogenic sampling tube during the condensation process, some laboratory investigations employing coated
Table 4. Measured and calculated $\left(\mathrm{H}_{2} \mathrm{O}_{2}\right)_{\mathrm{g}}$ concentrations in air during a rain event on September 13,1985

\begin{tabular}{llll}
\hline Time & $\begin{array}{l}\text { Rain } \\
\left(\mathrm{H}_{2} \mathrm{O}_{2}\right)_{1}, \text { meas. } \\
(\mathrm{w} / \mathrm{w})\end{array}$ & $\begin{array}{l}\mathrm{Air} \\
\left(\mathrm{H}_{2} \mathrm{O}_{2}\right)_{\mathrm{g}}, \text { calc. } \\
(\mathrm{v} / \mathrm{v})\end{array}$ & $\begin{array}{l}\text { Air } \\
\left(\mathrm{H}_{2} \mathrm{O}_{2}\right)_{\mathrm{g}}, \text { meas. } \\
(\mathrm{v} / \mathrm{v})\end{array}$ \\
\hline 16.50 & $1114 \mathrm{ppb}$ & $192 \mathrm{ppt}$ & $54 \mathrm{ppt}$ \\
17.15 & $273 \mathrm{ppb}$ & $47 \mathrm{ppt}$ & $42 \mathrm{ppt}$ \\
17.42 & $95 \mathrm{ppb}$ & $16 \mathrm{ppt}$ & $42 \mathrm{ppt}$ \\
\hline
\end{tabular}

denuders as collectors [36-38] were undertaken. Sodium tetraborate proved to be a very effective coating material, with the advantage of being the right buffer for the chemiluminescence determination method.

Reproducible generation of $\left(\mathrm{H}_{2} \mathrm{O}_{2}\right)_{\mathrm{g}}$ test gas was obtained both with a capillary dispenser (Fig. 7) and a PTFE porous membrane diffusion tube (Fig. 8), both thermostated at $18^{\circ} \mathrm{C}$ to avoid water vapor condensation on the internal walls of the PTFE tubing and silicon rubber connections used for carrier gas and test gas mixture transport, respectively. Both generators gave a sufficiently stable output over $24 \mathrm{~h}$ but the day to day reproducibility of the diffusion tube was better than that of the capillary dispenser (Fig. 9). Figure 10 shows the complete laboratory set-up for generation and collection of $\mathrm{H}_{2} \mathrm{O}_{2}$. 


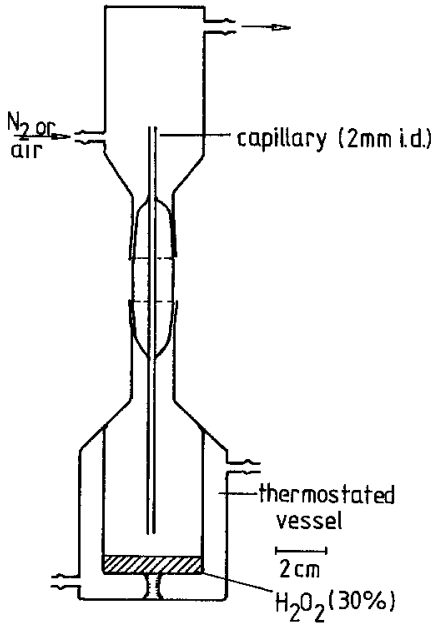

Fig. 7.

Capillary dispenser

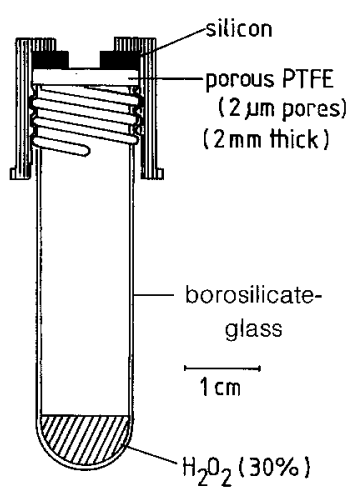

Fig. 8

Diffusion tube

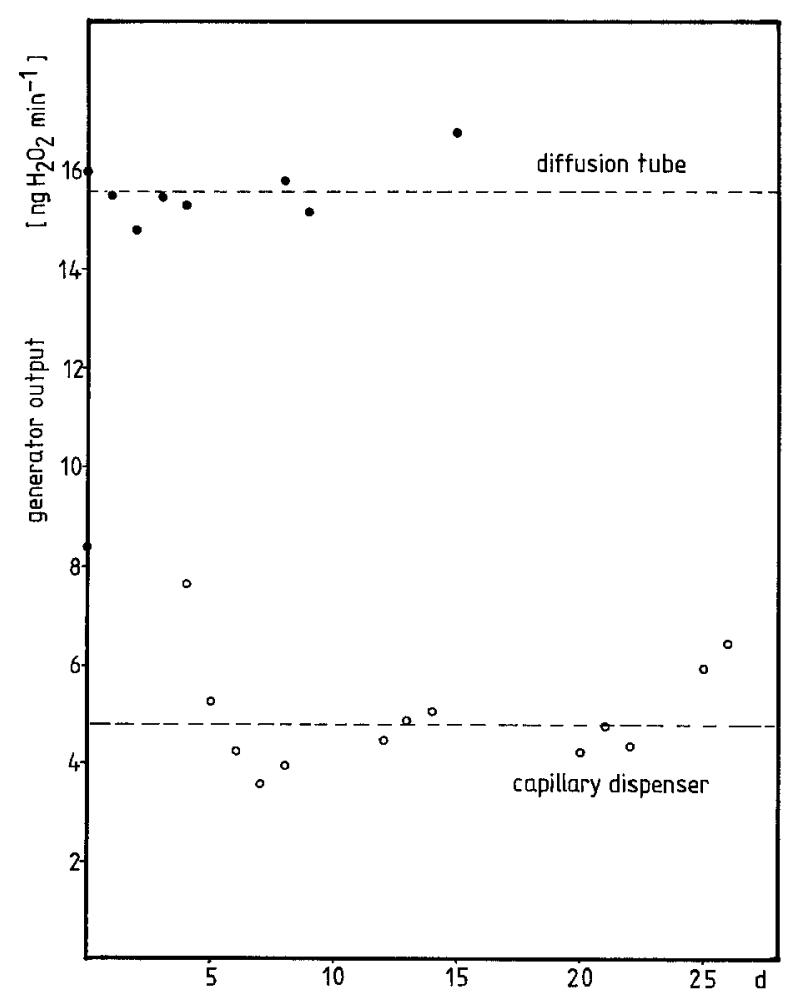

Fig. 9. Day to day variations in the output of the $\mathrm{H}_{2} \mathrm{O}_{2}$ test gas source

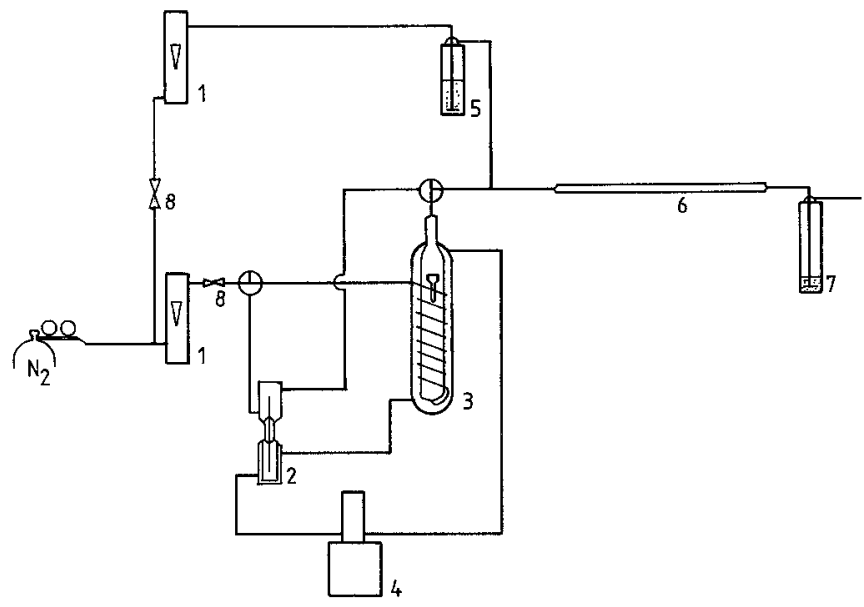

Fig. 10. Laboratory set-up for $\mathrm{H}_{2} \mathrm{O}_{2}$ generation and collection: 1 Flowmeter; 2 capillary dispenser; 3 thermostated diffusion tube; 4 thermostat; 5 humidifier; 6 denuder; $7 \mathrm{H}_{2} \mathrm{O}_{2}$ scrubber (water); 8 needle valve

Brown borosilicate glass tubes, $6 \mathrm{~mm}$ i.d., $60 \mathrm{~cm}$ length, were coated with sodium tetraborate by employing $500 \mu \mathrm{l}$ of a $0.026 \mathrm{M}$ solution of $\mathrm{Na}_{2} \mathrm{~B}_{4} \mathrm{O}_{7}$ in methanol and used as denuders. Brown tubes (or other light protecting means) are necessary to avoid photochemically induced production or decomposition of $\mathrm{H}_{2} \mathrm{O}_{2}$. Because diffusivity of $\left(\mathrm{H}_{2} \mathrm{O}_{2}\right)_{\mathrm{g}}$ is $0.18 \mathrm{~cm}^{2} \cdot \mathrm{s}^{-1}\left(20^{\circ} \mathrm{C}\right)$ [31] the dimensions of the denuder tubes chosen allow air sampling flow rates up to $100 \mathrm{l} / \mathrm{h}$ according to Davies' equation $[34,35]$. This implies $2-6 \mathrm{~h}$ sampling time for the $\left(\mathrm{H}_{2} \mathrm{O}_{2}\right)_{\mathrm{g}}$ concentration ranges generally found at Dortmund (cf. Figs. 2-5). After sampling, the tetraborate coating was removed from each tube with $1 \mathrm{ml}$ of bidistilled water, and $200 \mu \mathrm{l}$ aliquots of each extract were analysed by the chemiluminescence technique already described [30].

Laboratory investigations of denuder sampling of $\left(\mathrm{H}_{2} \mathrm{O}_{2}\right)_{\mathrm{g}}$ employing test gas mixtures showed very good collection efficiency $(95 \%)$ and overall recovery $(96 \%)$. However, ozone interferes by formation of artifact $\mathrm{H}_{2} \mathrm{O}_{2}$. Therefore field results obtained by denuder sampling were higher by a factor of 3-10 compared with the $\left(\mathrm{H}_{2} \mathrm{O}_{2}\right)_{\mathrm{g}}$ levels found by cryogenic sampling. The elimination of the ozone interference is presently being studied by our group.

Acknowledgements. This work was financially supported by the Minister of Science and Research of the State of NordrheinWestfalen.

One of us (T.M.T.) gratefully acknowledges travel support by Stiftung Volkswagenwerk.

\section{References}

1. Penkett SA, Jones BMR, Brice KA, Eggleton AEJ (1979) Atmos Environ 13:123-137

2. Möller D (1980) Atmos Environ 14:1067-1076

3. Martin LR, Damschen DE (1981) Atmos Environ 15:16151621

4. Kunen SM, Lazrus AL, Kok GL, Heikes BG (1983) J Geophys Res $88: 3671-3674$

5. Schwartz SE (1984) J Geophys Res 89:11589-11598

6. Chameides WL, Davis DD (1982) J Geophys Res 87:48634877

7. Hewitt CM, Harrison RM (1985) Atmos Environ 19:545-554

8. Logan JA, Prather MJ, Wofsy SC, McElroy MB (1981) J Geophys Res 86:7210-7254 
9. Thompson AM, Cicerone RJ (1982) J Geophys Res 87:88118826

10. Adewuyi YG, Cho SY, Tsay RP, Carmichael GR (1984) Atmos Environ 18:2413-2420

11. Graedel TE, Goldberg KT (1983) J Geophys Res 88:1086510882

12. Kok GL, Holler TP, Lopez MB, Nachtrieb HA, Yuan M (1978) Environ Sci Technol 12:1072-1076

13. Bufalini JJ, Gay BW, Brubaker KL (1972) Environ Sci Technol $6: 816-821$

14. Pilz W, Johann I (1974) Intern Environ Anal Chem 3:257270

15. Das TN, Moorthy PN, Rao KN (1983) Atmos Environ 17:7982

16. ten Brink HM, Kelly TJ, Schwartz SE (1984) European symposion on the physico-chemical behavior of atmospheric pollutants, Varese, April 1984

17. Daum PH, Kelly TJ, Schwartz SE, Newman L (1984) Atmos Environ 18:2671-2684

18. Gay BW Jr, Bufalini JJ (1972) Environ Lett 3:21 -24

19. Kok GL, Darnall KR, Winer AM, Pitts JN Jr, Gay BW (1978) Environ Sci Technol 12:1077-1080

20. Das TH, Moorthy PN, Rao KN (1982) J Ind Chem Soc 59:85 88

21. Kok GL, Gay BW Jr (1983) EPA -600/3-83-030

22. Zika RG, Saltzman E (1982) Geophys Res Lett 9:231-234

23. Heikes BG, Lazrus AL, Kok GL, Kunen SM, Gandrud BW, Gitlin SN, Sperry PD (1982) J Geophys Res 87:3045-3051

24. Heikes BG (1984) Atmos Environ 18:1433-1445
25. Schöne E (1878) Ber Dtsch Chem Ges $11: 561-566$

26. Quittmann E, Cauer H (1939) Fresenius Z Anal Chem 116:81 91

27. Farmer JC, Dawson GA (1982) J Geophys Res 87:8931 - 8942

28. Kelly TJ, Stedman DH (1979) Geophys Res Lett 6:375-378

29. Kadlecek J, McLaren S, Camarota N, Mohnen V, Wilson J (1983) In: Pruppacher HR, Semonin GR, Slinn WGN (eds) Precipitation scavenging, dry deposition and resuspension, vol 1. Elsevier, Amsterdam, pp 103-114

30. Klockow D, Jacob P (1986) In: Jaeschke W (ed) Chemistry of multiphase atmospheric systems. Springer, Berlin Heidelberg New York Tokyo, pp 117-130

31. Yoshizumi K, Aoki K, Nouchi I, Okita T, Kobayashi T, Kamakura S, Tajima M (1984) Atmos Environ 18:395-401

32. Lazrus AL, Kok GL, Gitlin SN, Lind JA, McLaren SE (1985) Anal Chem 57:917-922

33. Chameides WL, Davis DD (1982) Chemistry in the troposphere (Special Report) Chem Eng: $38-52$

34. Davies CN (1946) Proc Roy Soc Belg 133:282-299

35. Gormley P, Kennedy M (1949) Proc R Irish Acad 52A:163169

36. Niessner R, Klockow D (1983) J Aerosol Sci 15:175-179

37. Ferm M (1979) Atmos Environ 13:1385-1393

38. Slanina J, v. Lamoen-Doornenbal L, Lingerak WA, Meilof W, Klockow D, Nießner R (1981) Int J Environ Anal Chem 9: $59-70$

Received February 12, 1986 